or "ramble"". From the wording of the report the reader might suppose that the term 'ramble' is confined to this particular coal, but as a matter of fact it is a genoric term for any thin bed of shaly matter that comes down when the underlying coal is worked. Thus in the "Glossary of Terms used in the Coal Trade of Northumberland and Durham ", by G. C. Greenwell, the first edition, published in 1849, defines ramble as "A thin stratum of shale, often found lying immediately above the seam of coal. It falls down, and, getting mixed with the coals, causes some trouble to the hewer, in getting it separated and cast back." Seeing that this brat, although described as dirty coal, is stated to have contained in one place as much as 69 per cent of ash, whereas one of the bands of shale contains only 46 per cent, it is obvious that this band might fairly come within Greenwell's definition. Perhaps the most interesting statement in the roport is that the authors find "the coking properties of the seam to be weak, but not nonexistent"; seeing that Northumbrian coals are generally supposed to be non-coking, this statement is a very important one, and leads to the inference that the Yard Seam smalls may be useful for blending with more strongly coking coals in order to produce a good metallurgical coke.

\section{Cormorant Fishing in China}

IT is sometimes said that since the neolithic age man has made no progress in domesticating wild creatures, oxcept for the improvements made in the breeds of animals domesticated at that time. But the domestication of the cormorant in China belongs to a much more recent period. The story has been worked out in detail by Berthold Laufer of the Field Museum of Natural History, Chicago (Field Museum Publication 300, Anthropological Series, vol. 18, 1931). The earliest mention of the use of trained cormorants for fishing refers to Japan and dates from about A.D. 607, when, presumably, such use was unknown in China. Yet the trained cormorants of Japan are scarcely more domesticated than the English cormorants which James I. delighted to watch, and for whom he appointed a 'master of the royal cormorants'. In China the birds are completely domesticated, being bred and reared in captivity, so that they become perfectly submissive to their masters, whose commands they understand, and whom they obey with the readiness and docility of a dog. Characteristic of their domestication is the appearance amongst them of colour varieties, particularly of albinistic and pied individuals. Their eggs are always hatched by domestic fowls and not by the cormorant mother, and the young are fed on special foods until the period of their training for fishing begins, and this lasts for seven or eight months.

\section{Investigations of Isotopes in 1931}

IN the Berichte der deutschen chemischen Gesellschaft for January 1932 will be found a report by Prof. O. Hahn upon the progress made during the year 1931 in the investigation of isotopic forms of the elements. In a footnote it is explained that the German Chemical Society has arranged for the continuation of such reports upon this subject until such time as an international commission shall have been set up for the purpose. The present report supplements the last biennial report, published in London nearly a year ago in the Annual Reports of the Chemical Society. After referring to the now determination by Mecke and Childs of the relative proportions in oxygen of its isotopes, and to the desirability of retaining oxygen for the present as the standard in estimating atomic weights in spite of its complex nature, the author of the report reviews the latest developments obtained by moans of the mass-spectrograph and of band spectra. Two useful tables are appended, containing respectively a list of sixty-three elements, which have hitherto been examined, together with their isotopes, and a list of no fewer than thirty-six pairs of isobars of nonradioactive elements.

\section{American Geophysical Union}

THE Transactions of the American Geophysical Union (published by the National Research Council) at its twelfth annual meeting, on April 30-May 1, 1931, appeared in June. This promptness, due to the able organisation of the secretary, Dr. J. A. Fleming, and to the use of direct reproduction from typescript, much enhances the value of the report. From its 227 pages geophysicists elsewhere can obtain a rapid and comprehonsive view of the large amount of work in this field now being done in the United States and, to a certain extent, in Canada and Mexico. The general assembly was mainly devoted to a symposium on time-signals; most of the work of the meeting is done in the seven sectional meetings. In seismology, the papers related chiefly to the development of new or improved instruments; in meteorology, to the work of the International Polar Year ; in terrestrial magnetism and electricity, including radio work, the papers were very numerous and covered a wide range of subjects ; in oceanography, the reports of many institutions on their past work were the main subject of discussion; hydrology forms a separate section, and had a long and varied programme; and there were a few papers on volcanology.

\section{Apparatus for Absorption Spectrophotometry}

Messes. Adam Hilger, Ltd., have published an interesting booklet dealing with the outfits they supply for absorption spectrophotometry in the visible and ultra-violet regions. The most important new instrument which is described is a form of ultra-violet spectrophotometer, working on the principle of the variation of the aperture of the beam, for which the name Spekker has been registered. This has been designed primarily for use with Hilger's medium quartz spectrographs, but may be attached to any similar instrument of sufficiently great aperture. Judging by the description of the instrument, and by a specimen set of absorption photographs for benzene in hexane, this should be both highly convenient to use and accurate in the results it yields. A photoelectric outfit is also described, although not very enthusiastically, the opinion being expressed that the use of a photoelectric cell in place of the eye or a photographic record diminishes the likelihood of a number of important sources of error being recognised, so that

$$
\text { No. 3250, VoL. 129] }
$$


there is a liability that copious and apparently highly accurate results may be amassed which are actually unreliable. Other devices listed include Bay and Steiner's hydrogen discharge tubes for providing continuous ultra-violet sources of light, and also a micrometer liquid cell for studying the absorption of thin layers of liquid.

\section{Biology in Shakespeare}

IT would be indeed a difficult problem to conceive of any new point of view from which to study Shakespeare's works. In the Scientific Monthly for January, Prof. Fraser-Harris has made a study of the world's greatest poet and dramatist from the point of view of biology, and though the topic is not a new one-there is a public garden in Manchester where nearly all the plants, wild and cultivated, mentioned in Shakespeare are grown, and references given-the method is new, in that Prof. FraserHarris has aimed, not at giving a catalogue of plants and animals, but at considering a few allusions which are of distinctly physiological or psychological interest. For example, Prof. Fraser-Harris claims four participating factors in sleep-chemical, vascular, sensory, and ideational; and Shakespeare recognises two of these in the famous soliloquy of the king in "Henry IV". Although Shakespeare was a contemporary of Harvey, there is no reference in his works to blood circulation, and though one might express surprise at this, Prof. Fraser-Harris gives sufficient argument why Shakespeare was ignorant of the then new discovery. These are only two examples of how Shakespearean lines embody deep biological truths ; many more, with the appropriate quotations and commentaries, are given by Prof. Fraser-Harris in his interesting article.

\section{Veterinary Research in South Africa}

WE have received the seventeenth report of the Director (Prof. P. J. du Toit) of Veterinary Services and Animal Industry, Onderstepoort, Pretoria (Union of S. Africa : Dep. of Agriculture. The Government Printer, Pretoria, 1931. 10s. each part). It is issued in two parts of about 425 pages each, is well produced and fully illustrated, and contains a mass of valuable material dealing with all branches of veterinary research and animal industry. Part 1 contains the parasitological matter, part 2 physiological, pathological, and industrial subjects and metabolism. Of general interest may be mentioned papers on a new and cheap method of preparing pure cystine from wool, and giving a high yield, by J. G. Louw; the good effects of sulphur on merino sheep in doses of $5 \mathrm{gm}$. from once to six times weekly, the general condition of the animals, weight, and wool yield being strikingly improved, by D. G. Steyn; and the improved quality of bacon obtained by including barley meal in the pig's ration, by D. J. Schulte and C. A. Murray.

\section{British Lenses}

We learn from Messrs. Taylor, Taylor and Hobson, Ltd., that they have recently received a contract for no less than 350,000 lenses, totalling more than half a million glasses, for inexpensive hand cameras.
Messrs. Taylor, Taylor and Hobson produce costly Cooke lenses used in some of the world's leading observatories for stellar photography, and also highly corrected Cooke lenses of large aperture for the exacting requirements of the principal cinema studios throughout Britain and the United States. It is the high degree of precision demanded by these more expensive products that has enabled the firm to design and make machinery capable of producing inexpensive lenses in such quantities and in competition with such low Continental prices as those for which the above contract has been awarded.

\section{Eskimo Settlement in Alaska}

AN expedition of the University of Pennsylvania Museum, of which Miss Frederica de Laguna is the leader, working in Alaska during the past season, reports the discovery, according to Science Service, of a prehistoric Eskimo settlement at Cook's Inlet. This area is at present inhabited by Indians, and the settlement would appear to represent the most southerly extension of Eskimo culture known. Shell heaps on the shore, some of them ten to fourteen feet in height, have been investigated. Among the relics were a number of personal ornaments, including lip plugs, beads, an ivory pendant, a carved ivory head, and a nose-pin. The objects of domestic use included a lamp, a needle-case and needles, and an ivory catch for a box. One of the most interesting relics was a mirror of slate, of which the surface showed the reflection on being damped.

\section{Esperanto in Scientific Literature}

REFERRING to the recent correspondence in NATURE on Esperanto in scientific literature, Prof. W. E. Collinson, professor of German and John Buchanan lecturer in Esperanto in the University of Liverpool, has written stating that the fullest and most extensively documented account of such writings is Section 86 of Dr. Eugen Wüster's "Internationale Sprachnormung in der Technik-besonders in der Elektrotechnik" (published with the support of the Akademie des Bauwesens, VDI-Verlag, Berlin, 1931). This work deals with the problem of the international standardisation of technical nomenclature in all its aspects, and shows the wide range of topies in which work has already appeared in Fsperanto, namely, biochemistry, strength of materials, inorganic and organic chemistry, telephony and wireless, bacteriology, analytical geometry, etc.

\section{Postponement of an International Congress}

WE learn from the General Secretary, Prof. E. Moles, San Barnado 49, Madrid, that at a meeting of the Bureau of the International Union of Chemistry and the organising committee of the Ninth International Congress of Pure and Applied Chemistry held recently, it was decided to postpone the Congress indefinitely. The Congress was to have been at Madrid on April 3-10 this year, but it was felt that the present world-wide economic depression would limit seriously the usefulness of such a gathering. When conditions improve it is hoped to hold the Congress as originally arranged at Madrid.

(Continued on p. 241.)

No. 3250, VoL. 129] 